\title{
Correction to: Central line bundle including split-septum device and single-use prefilled flushing syringes to prevent port-associated bloodstream infections: a cost and resource-utilization analysis
}

\author{
Illker Devrim ${ }^{1 *}$, Mustafa Taha Özkul ${ }^{2}$, Ilknur Çağlar ${ }^{1}$, Yeliz Oruç̧ ${ }^{3}$, Nevbahar Demiray ${ }^{3}$, Neryal Tahta ${ }^{4}$ and \\ Canan Vergin ${ }^{4}$
}

Correction to: BMC Health Serv Res 20, 336 (2020) https://doi.org/10.1186/s12913-020-05221-6

Following publication of the original article [1], the authors would like to exchange the Table 1's caption and Table 2's caption. The correct ones are shown below.

The sentence of Table 1's caption currently reads:

The comparison of port days, central line days, CLABSI rate, hospital stay costs, drug costs, laboratory, and total costs

The sentence of Table 2's caption currently reads:

The distribution of microorganisms associated with CLABSI's associated with TIVADs

\section{Author details}

'Department of Pediatric Infectious Diseases, Dr. Behçet Uz Children's Hospital, İzmir, Turkey. ${ }^{2}$ Department of Pediatrics, Dr. Behçet Uz Children's Hospital Izmir, Izmir, Turkey. ${ }^{3}$ Department of Infection Control Committee, Dr. Behcet Uz Children's Hospital, Izmir, Turkey. ${ }^{4}$ Department of Pediatric Hematology and Oncology, Dr. Behçet Uz Children's Hospital, Izmir, Turkey.
Published online: 21 May 2020

\section{Reference}

1. Devrim, et al. Central line bundle including split-septum device and singleuse prefilled flushing syringes to prevent port-associated bloodstream infections: a cost and resource-utilization analysis. BMC Health Serv Res. 2020;20:336.

The original article can be found online at https://doi.org/10.1186/s12913020-05221-6

* Correspondence: ilkerdevrim2003@yahoo.com

'Department of Pediatric Infectious Diseases, Dr. Behçet Uz Children's Hospital, Izmir, Turkey

Full list of author information is available at the end of the article

(c) The Author(s). 2020 Open Access This article is licensed under a Creative Commons Attribution 4.0 International License, which permits use, sharing, adaptation, distribution and reproduction in any medium or format, as long as you give appropriate credit to the original author(s) and the source, provide a link to the Creative Commons licence, and indicate if changes were made. The images or other third party material in this article are included in the article's Creative Commons licence, unless indicated otherwise in a credit line to the material. If material is not included in the article's Creative Commons licence and your intended use is not permitted by statutory regulation or exceeds the permitted use, you will need to obtain permission directly from the copyright holder. To view a copy of this licence, visit http://creativecommons.org/licenses/by/4.0/ The Creative Commons Public Domain Dedication waiver (http://creativecommons.org/publicdomain/zero/1.0/) applies to the data made available in this article, unless otherwise stated in a credit line to the data. 